\title{
The Structural and Functional Differentiation of Hair Cells in a Lizard's Basilar Papilla Suggests an Operational Principle of Amniote Cochleas
}

\author{
M. Eugenia Chiappe, Andrei S. Kozlov, and A. J. Hudspeth \\ Howard Hughes Medical Institute and Laboratory of Sensory Neuroscience, The Rockefeller University, New York, New York 10065-6399
}

The hair cells in the mammalian cochlea are of two distinct types. Inner hair cells are responsible for transducing mechanical stimuli into electrical responses, which they forward to the brain through a copious afferent innervation. Outer hair cells, which are thought to mediate the active process that sensitizes and tunes the cochlea, possess a negligible afferent innervation. For every inner hair cell, there are approximately three outer hair cells, so only one-quarter of the hair cells directly deliver information to the CNS. Although this is a surprising feature for a sensory system, the occurrence of a similar innervation pattern in birds and crocodilians suggests that the arrangement has an adaptive value. Using a lizard with highly developed hearing, the tokay gecko, we demonstrate in the present study that the same principle operates in a third major group of terrestrial animals. We propose that the differentiation of hair cells into signaling and amplifying classes reflects incompatible strategies for the optimization of mechanoelectrical transduction and of an active process based on active hair-bundle motility.

Key words: active process; auditory system; gecko; hair bundle; hearing; reptile

\section{Introduction}

The occurrence of a common trait in different organisms can reflect either a common ancestry or the operation of selective pressure shared in the course of independent evolution. Because multiple independent instances of a particular trait are unlikely to occur by chance, they emphasize the importance of selective pressure. An example pertinent to the subject of this study is the independent development during the Triassic period of the tympanic middle ear by at least three groups of amniotes (Clack, 1997, 2002): the ancestors of mammals, of archosaurs (including crocodilians and birds), and of lepidosaurs (including lizards and snakes). The selective pressure operating on these three clades was the requirement for greater acoustic sensitivity that was achieved by reducing sound reflection at the air-liquid interface through impedance matching.

A second striking characteristic of the auditory system that apparently arose independently in mammals and archosaurs is the differentiation of hair cells into two structural and functional classes. One coterie of cells, which includes the inner hair cells of

\footnotetext{
Received April 24, 2007; revised Sept. 10, 2007; accepted Sept. 16, 2007.

This work was supported by National Institutes of Health Grant DC00241. M.E.C. was a predoctoral fellow, A.S.K. was an associate, and A.J.H. was an investigator of Howard Hughes Medical Institute. We thank Dr. L. Le Goff for help with data collection and processing and Drs. E. Fuchs and A. Pasolli for access to the transmission electron microscope. Dr. L. Petreanu and the members of our research group provided helpful comments on this manuscript.

Correspondence should be addressed to Dr. A. J. Hudspeth, Howard Hughes Medical Institute and Laboratory of Sensory Neuroscience, The Rockefeller University, 1230 York Avenue, Box 314, New York, NY 10065-6399. E-mail: hudspaj@rockefeller.edu.

M. E. Chiappe's present address: Janelia Farm Research Campus, Howard Hughes Medical Institute, 19700 Helix Drive, Ashburn, VA 20147.

DOI:10.1523/JNEUROSCI.3679-07.2007

Copyright $\odot 2007$ Society for Neuroscience $\quad$ 0270-6474/07/2711978-08\$15.00/0
}

mammals and the tall hair cells of archosaurs, is devoted to mechanoelectrical transduction and afferent synaptic signaling. The mechanosensitive hair bundles of these cells detect soundderived vibrations and transduce them into receptor potentials that trigger the release of synaptic transmitter. Hair cells of this signaling class receive copious afferent innervation but little or no efferent innervation.

The second class of hair cells comprises mammalian outer hair cells and archosaurian short hair cells. The hair bundles of these cells are also mechanosensitive, but their principal role is thought to be mediating the active process that sensitizes and tunes the responsiveness of the ear (Fettiplace and Hackney, 2006). Active hair-bundle motility is the basis of this active process in amphibians and reptiles (Martin and Hudspeth, 1999, 2001; Martin et al., 2000; Manley, 2001; Manley et al., 2001; Ricci et al., 2002). In mammals, both active hair-bundle motility and membranebased electromotility may contribute to the active process (Chan and Hudspeth, 2005a,b; Kennedy et al., 2005, 2006; Dallos et al., 2006). Consistent with their role as amplifiers, outer hair cells and short hair cells make few or no synapses onto afferent nerve fibers. Instead, they receive an extensive efferent input that regulates their mechanical activity.

In its sensitivity, frequency range, and tuning, the acoustic performance of certain lepidosaurs rivals that of mammals and archosaurs (Manley and Köppl, 1998; Manley, 2000). To inquire whether the dichotomous organization of hair cells extends to some of the 21 families of lizards, we have examined the physiological properties and innervation of hair cells from the tokay gecko. As a member of one of the few lizard families that uses vocal signals in territoriality, mating, and distress alerts, this species is particularly dependent on an effective auditory system. In 
addition to providing evidence of the differentiation between two classes of hair cells in this lizard, we propose here a biophysical principle that may represent the adaptive value underlying the repeated evolution of this trait.

\section{Materials and Methods}

Cochlear isolation. In each experiment, a juvenile tokay gecko (Gekko gecko) of $\sim 30$ g mass was decapitated after being killed with an intraperitoneal injection of $300 \mathrm{mg} \cdot \mathrm{kg}^{-1}$ sodium pentobarbital (Nembutal; Abbott Laboratories, Abbott Park, IL). The lower jaw was removed to expose the ventral floor of the skull, which was bisected along its midline. The exposed brain tissue was discarded after cutting the eighth cranial nerve at its entrance to the brain. In this way, the otic capsule was rendered accessible from its ventromedial aspect, from which it was widely opened with forceps. The intact otic labyrinth was removed and immersed in oxygenated low- $\mathrm{Ca}^{2+}$ artificial perilymph containing (in mм) $168 \mathrm{NaCl}, 3 \mathrm{KCl}, 0.5 \mathrm{CaCl}_{2}, 1.2 \mathrm{MgCl}_{2}, 2 \mathrm{Na}_{2} \mathrm{SO}_{4}, 5 \mathrm{D}$-glucose, 1 sodium pyruvate, 1 creatine, 20 sucrose, and $0.5 \mathrm{NaH}_{2} \mathrm{PO}_{4}, \mathrm{pH}$ 7.3. Except where otherwise noted, all chemicals were obtained from Sigma (St. Louis, $\mathrm{MO}$ ). The cochlear duct, including the basilar papilla and lagena, was isolated by cutting away the semicircular canals, utricle, and saccule.

Electrophysiology. After dissection, a cochlea was transferred to a small dish containing low- $\mathrm{Ca}^{2+}$ artificial perilymph with $2 \%$ low-gellingtemperature agarose. The agar block was mounted on the platform of a Vibratome (VT 1000 T; Leica, Nussloch, Germany) and sliced in an ice-cold solution at intervals of $250-300 \mu \mathrm{m}$. Until they were used for recordings, slices were stored at $22-25^{\circ} \mathrm{C}$ in oxygenated low-Ca ${ }^{2+}$ artificial perilymph containing $10 \mathrm{U} \cdot \mathrm{ml}^{-1}$ deoxyribonuclease $\mathrm{I}$. The recordings were performed in artificial perilymph containing $2 \mathrm{mM} \mathrm{Ca}^{2+}$.

Borosilicate glass pipettes were pulled with a horizontal puller ( $\mathrm{P}-80$ / PC; Sutter Instruments, Novato, CA) and fire-polished to a tip diameter of $\sim 1 \mu \mathrm{m}$ and a resistance of 4-6 M $\Omega$. Unless noted otherwise, each recording pipette was filled with a solution containing $155 \mathrm{~mm} \mathrm{KCl,} 2 \mathrm{mM}$ $\mathrm{MgCl}_{2}, 20$ mм sucrose, 1 mм EGTA, and 5 mm HEPES, pH 7.3.

Cells were visualized on an upright microscope (Axioscope 2; Carl Zeiss, Oberkochen, Germany) equipped with a $63 \times$ water-immersion objective lens and differential interference contrast optics. Whole-cell currents were recorded using an Axopatch 200B amplifier (Molecular Devices, Union City, CA). During recordings, the series resistance was usually 7-15 $\mathrm{M} \Omega$, of which at least $75 \%$ was electronically compensated. The command voltage was corrected for errors because of the uncompensated series resistance of 1-4 M $\Omega$.

Experiments were performed at a room temperature of $20-25^{\circ} \mathrm{C}$. Except when noted, all voltage-clamp pulses were applied from a holding potential of $-70 \mathrm{mV}$, and the resulting currents were averaged five times. Because high-frequency hair cells displayed strongly nonlinear voltagecurrent relationships, it was difficult to find a voltage range in which to apply a protocol for leak subtraction. Currents were instead leaksubtracted by computing the slope of the linear relationship between membrane potential and current when all voltage-dependent conductances were blocked. The corresponding leak currents were calculated by extrapolating this linear fit to the series of applied voltage steps.

When used at submillimolar concentrations, pharmacological agents were added to the artificial perilymph. Otherwise, chemicals substituted for $\mathrm{NaCl}$ in equimolar concentrations. Bay K 8644 (1,4-dihydro-2,6-dimethyl-S-nitro-4-[2(trifluoromethyl)phenyl]-3pyridinecarboxylic acid methyl ester), nifedipine, and ZD-7288 [4-(N-ethyl-N-phenylamino)-1,2-dimethyl-6-methylaminopyrimidinium chloride were obtained from Tocris Bioscience (Ellisville, $\mathrm{MO})$. All external solutions were adjusted to a $\mathrm{pH}$ of 7.3.

Data analysis. Data were analyzed with Matlab (version 7; MathWorks, Natick, MA). For all recordings, the uncompensated series resistance was calculated as described previously (Smotherman and Narins, 1999). Recordings were analyzed if the series resistance was lower than 15 $\mathrm{M} \Omega$, and the calculated values of the membrane capacitance and uncompensated series resistance differed by $<5 \%$ from those measured on-line with the amplifier.

For determining activation time constants, currents were fit with a single- or double-exponential relationship. The Boltzmann functions used here were of the following form:

$$
\frac{I}{I_{\mathrm{MAX}}}=\frac{1}{1+e^{\left(V_{1 / 2}-V_{M}\right) / k}}
$$

where $I / I_{\max }$ is the current relative to its maximal value, $V_{1 / 2}$ is the potential of half-activation, $V_{\mathrm{M}}$ is the membrane potential, and $k$ is a slope factor. Steady-state current amplitudes were determined by averaging the last $20 \mathrm{~ms}$ of the 50 or $100 \mathrm{~ms}$ voltage steps. Voltage-current relationships were fit at steady state with the following function:

$$
I=\frac{G_{M A X}\left(V_{M}-E_{C a}\right)}{1+e^{\left(V_{1 / 2}-V_{M}\right) / k}}
$$

where $I$ is the $\mathrm{Ca}^{2+}$ current, $G_{\mathrm{MAX}}$ is the maximal conductance, $V_{\mathrm{M}}$ is the membrane potential, $E_{\mathrm{Ca}}$ is the extrapolated reversal potential of the $\mathrm{Ca}^{2+}$ current, $V_{1 / 2}$ is the potential of half-activation, and $k$ is a slope factor.

Unless noted otherwise, results are presented as means \pm SDs. Statistical significance was assessed with the parametric Student's $t$ test or, in some instances, with the nonparametric Student's $U$ test.

Immunofluorescent labeling. Isolated cochleas were incubated for $2 \mathrm{~h}$ at $4^{\circ} \mathrm{C}$ in PBS solution containing 4\% paraformaldehyde (Electron Microscopy Sciences, Fort Washington, PA) and 0.1\% Triton X-100. After having been washed twice for $10 \mathrm{~min}$ in PBS solution containing detergent the fixed cochleas were incubated for $30 \mathrm{~min}$ in that solution supplemented with 5\% heat-inactivated horse serum (Invitrogen, San Diego, CA) to reduce nonspecific binding of primary antibodies.

For the production of cryosections, overnight fixation of the cochleas in the absence of detergent was followed by a $12 \mathrm{~h}$ incubation in increasing concentrations of sucrose that culminated in a $30 \%$ sucrose solution. The cochleas were mounted in plastic molds in embedding medium (Tissue-Tek OCT; Qiagen, Chatsworth, CA) and frozen in ethanol cooled with solid $\mathrm{CO}_{2}$. The cochleas were cross sectioned at $20 \mu \mathrm{m}$ intervals, and the sections were collected on glass slides. After a brief refixation, the tissue was permeabilized for $30 \mathrm{~min}$ in PBS solution containing $0.1 \%$ Triton X-100 and transferred to a solution containing $5 \%$ heatinactivated horse serum (Invitrogen).

Auditory nerve fibers were immunolabeled at a 1:100 dilution of a rabbit polyclonal antiserum (NF200; Sigma) that specifically recognizes the $200 \mathrm{kDa}$ neurofilament-associated protein. Whole-mount cochleas and cryosections were first incubated with primary antibodies overnight at $4^{\circ} \mathrm{C}$ and then exposed to fluorophore-conjugated secondary antibodies (Invitrogen) at a 1:200 dilution. Micrographs were acquired with an upright microscope (Axioscope 2; Carl Zeiss) equipped with a laserscanning confocal system (LSM 510; Carl Zeiss) and subsequently analyzed with the associated software.

Scanning electron microscopy. After decapitation and medial opening of the head had been performed as detailed above, loose otoconia were removed with a stream of the low- $\mathrm{Ca}^{2+}$ artificial perilymph. Specimens were then immersed for $2 \mathrm{~h}$ at $4^{\circ} \mathrm{C}$ in a fixative solution containing 200 mu glutaraldehyde (Electron Microscopy Sciences), $1 \mathrm{~mm} \mathrm{CaCl}_{2}, 25 \mathrm{~mm}$ sucrose, and $120 \mathrm{~mm}$ sodium cacodylate, $\mathrm{pH}$ 7.2. A brief wash in the same solution without glutaraldehyde was followed by $1 \mathrm{~h}$ postfixation at $4^{\circ} \mathrm{C}$ in $50 \mathrm{~mm} \mathrm{OsO}_{4}, 1 \mathrm{~mm} \mathrm{CaCl}_{2}, 25 \mathrm{~mm}$ sucrose, and $120 \mathrm{~mm}$ sodium cacodylate, $\mathrm{pH}$ 7.2. After a wash in distilled water, the cochleas were dehydrated by immersion for 10 min each in 30, 50, 70, 80, and 95\% ethanol. After $2 \mathrm{~h}$ of dehydration in $100 \%$ ethanol, specimens were critical-point dried from liquid $\mathrm{CO}_{2}$ (Autosamdri-815; Tousimis Research, Rockville, $\mathrm{MD})$, sputter-coated with gold-palladium, and examined with a $30 \mu \mathrm{m}$ aperture and an accelerating voltage of $5 \mathrm{kV}$ in a microscope with a field-emission electron source (LEO 1550).

Transmission electron microscopy. Decapitation and medial opening of the head were performed as described. After opening of the otic capsule, however, the dissection continued under primary fixative solution containing $200 \mathrm{~mm}$ glutaraldehyde, $400 \mathrm{~mm}$ formaldehyde, $0.5 \mathrm{~mm} \mathrm{CaCl}$, and $70 \mathrm{~mm}$ sodium cacodylate, $\mathrm{pH}$ 7.2. Isolated cochleas were exposed to this solution at room temperature for an additional $17-20 \mathrm{~h}$. The tissue 
was postfixed by incubation at $4^{\circ} \mathrm{C}$ for $2 \mathrm{~h}$ in a solution containing $50 \mathrm{~mm}$ $\mathrm{OsO}_{4}, 10 \mathrm{~mm}$ potassium ferrocyanide, $0.5 \mathrm{mM} \mathrm{CaCl}_{2}$, and $70 \mathrm{~mm}$ sodium cacodylate, $\mathrm{pH}$ 7.2. After washes with distilled water, the cochleas were dehydrated through a graded series of ethanol concentrations as indicated above.

Additional electron density was conferred by treatment with $0.4 \%$ uranyl acetate in $95 \%$ ethanol for $1 \mathrm{~h}$ at room temperature. The tissue was dehydrated by immersion for $2 \mathrm{~h}$ in $100 \%$ ethanol and for $1 \mathrm{~h}$ in propylene oxide at room temperature. Each specimen was impregnated with an epoxy-resin mixture (EMbed-812; Electron Microscopy Sciences), transferred to a flat silicone embedding mold, and heated under vacuum for $48 \mathrm{~h}$ at $50^{\circ} \mathrm{C}$ to cure the plastic.

Specimens were sectioned at a thickness of $70 \mathrm{~nm}$ with a diamond knife (Ultra $45^{\circ}$; Diatome, Biel, Switzerland) in an ultramicrotome (Ultracut-E; Leica). Serial sections were collected and stained for $2 \mathrm{~min}$ with $50 \%$ saturated aqueous uranyl acetate in $50 \%$ acetone and for $1.5 \mathrm{~min}$ with lead salts. Micrographs were acquired with a transmission electron microscope (G2-12 Biotwin; Tecnai FEI, Hillsboro, OR) equipped with a digital camera (XR60; Advanced Microscopy Techniques, Danvers, MA).

\section{Results}

\section{Structure of the tokay gecko's basilar papilla}

The cochlea of the tokay gecko contains a sensory epithelium, the basilar papilla, $\sim 2 \mathrm{~mm}$ in length (Fig. $1 A, B$ ) (Authier and Manley, 1995). The basal (or dorsal) third of the papilla, which is responsive to frequencies below $1 \mathrm{kHz}$, is entirely covered by a thin, continuous mesh of tectorial material (Fig. $1 C$ ). In the apical (or ventral) two-thirds of the organ, which represents frequencies of $1-7 \mathrm{kHz}$, two distinct tectorial structures occur side by side across the width of the sensory epithelium (Fig. 1D). On the neural (or preaxial) side of the basilar papilla, where a broad band of nerve fibers enters the structure, a continuous tectorial membrane covers the hair cells. This configuration implies that neighboring hair bundles are physically coupled along both their longitudinal and lateral axes. On the opposite, abneural (or postaxial) side of the papilla, there stand $\sim 170$ discrete tectorial structures called sallets (Miller, 1973; Manley, 1990). Each sallet interconnects firmly the hair bundles in a transverse row of two to seven hair cells with similar frequency selectivity. Because only thin strands link the sallets longitudinally, however, these hair cells are less tightly coupled to those in the two neighboring rows under distinct sallets. An area devoid of hair cells, the hiatus, separates the tectorial from the salletal hair cells. The spindle body, a thin sheet of fibrous material (Manley, 1990), connects the tectorial structures of the neural edge to the limbic lip, a ridge of cartilage that arches over the papilla like a breaking wave (Fig. 1D).

\section{Electrical properties of the gecko's hair cells}

The two structural and functional classes of hair cells in mammals and archosaurs differ in their electrophysiological properties. For example, mammalian inner hair cells lack the prominent nonlinear capacitance associated with the membrane-based electromotility of outer hair cells (Dallos, 1992; Nobili et al., 1998; Dallos et al., 2006). Another, less dramatic difference occurs in the level of expression of certain ion conductances: the macroscopic currents through $\mathrm{Ca}^{2+}$ and $\mathrm{Ca}^{2+}$-activated $\mathrm{K}^{+}$channels in mammalian inner hair cells and avian tall hair cells exceed those in the corresponding cells of the other type (Kros and Crawford, 1990; Martinez-Dunst et al., 1997; Kros et al., 1998; Skinner et al., 2003; Pyott et al., 2004; Knirsch et al., 2007).

To test whether the hair cells covered by distinct tectorial structures in the gecko also differ electrophysiologically, we developed a slice preparation of the lizard's cochlea. After the entire organ had been embedded in agar, we cut transverse slices from
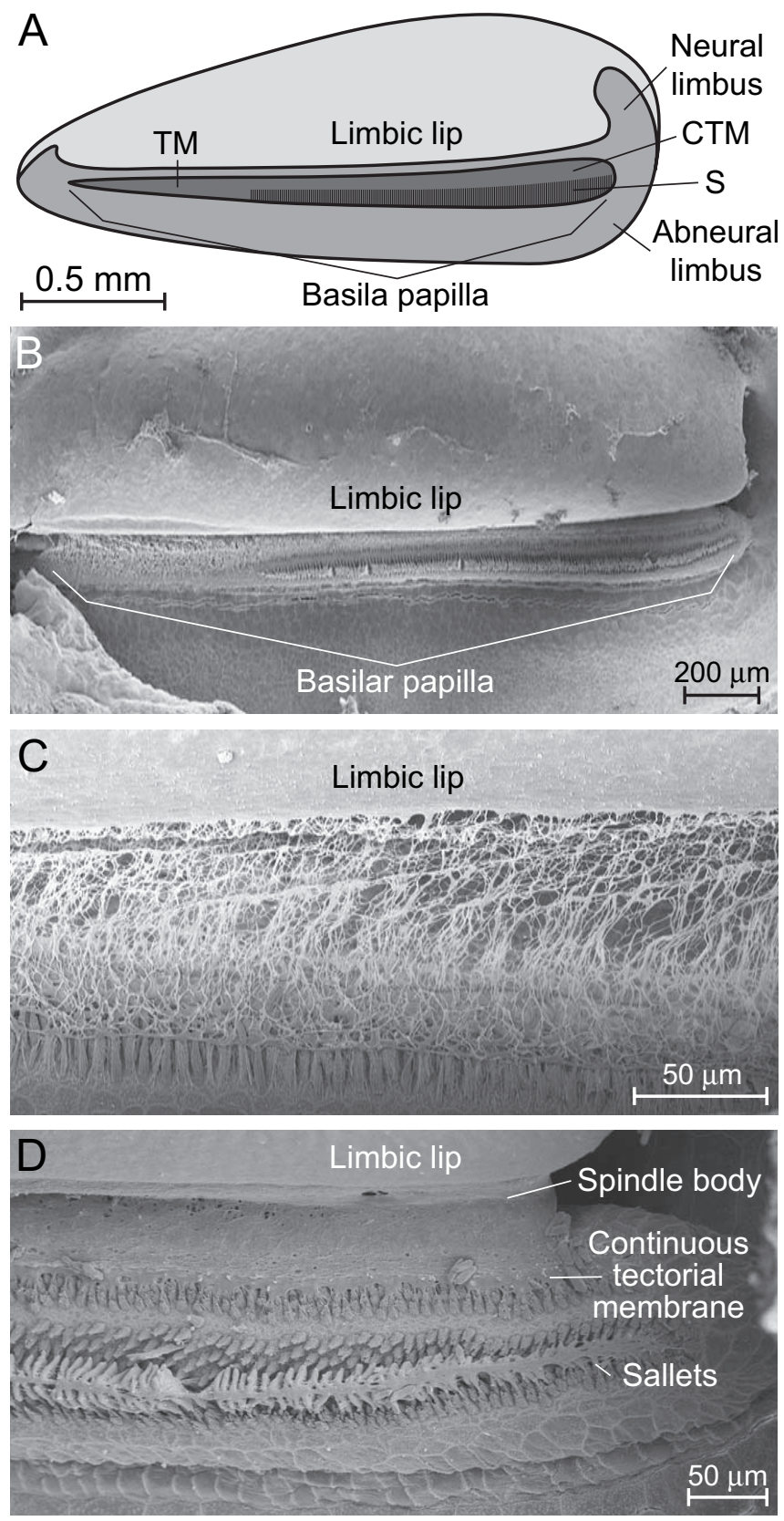

Figure 1. Structure of the tokay gecko's basilar papilla. $A$, The basilar papilla is supported by an oval cartilaginous limbus that protrudes along the neural edge as the limbic lip. The basilar papilla is covered by three different tectorial structures: in the basal, low-frequency region, by the tectorial mesh (TM); at the neural edge of the apical, high-frequency region, by the continuous tectorial membrane (CTM); and on the opposite side of the papilla, by an array of discontinuous tectorial units known as sallets (S). $\boldsymbol{B}$, A low-magnification scanning electron micrograph depicts the entire basilar papilla surmounted by the prominent limbic lip. C, In the basal region of the basilar papilla, all hair cells are covered by a thin mesh of tectorial material that inserts along the edge of the limbic lip. $\boldsymbol{D}$, The apical portion of the basilar papilla displays a parallel arrangement of hair cells covered by distinct tectorial structures. On the neural edge, a continuous tectorial material covers the tectorial hair cells and extends to the limbic lip through the spindle body. On the abneural side of the papilla, clusters of hair cells are covered by sallets.

the apex of the cochlea orthogonally to the tonotopic axis. Microscopic examination of a slice typically disclosed a sensory epithelium, the hair cells of which displayed normal shapes (Fig. $2 \mathrm{~A}$ ); the tectorial structures ordinarily remained attached to the hair bundles. We recorded from hair cells located on the basal side of the first slice and on the apical side of the second. These 

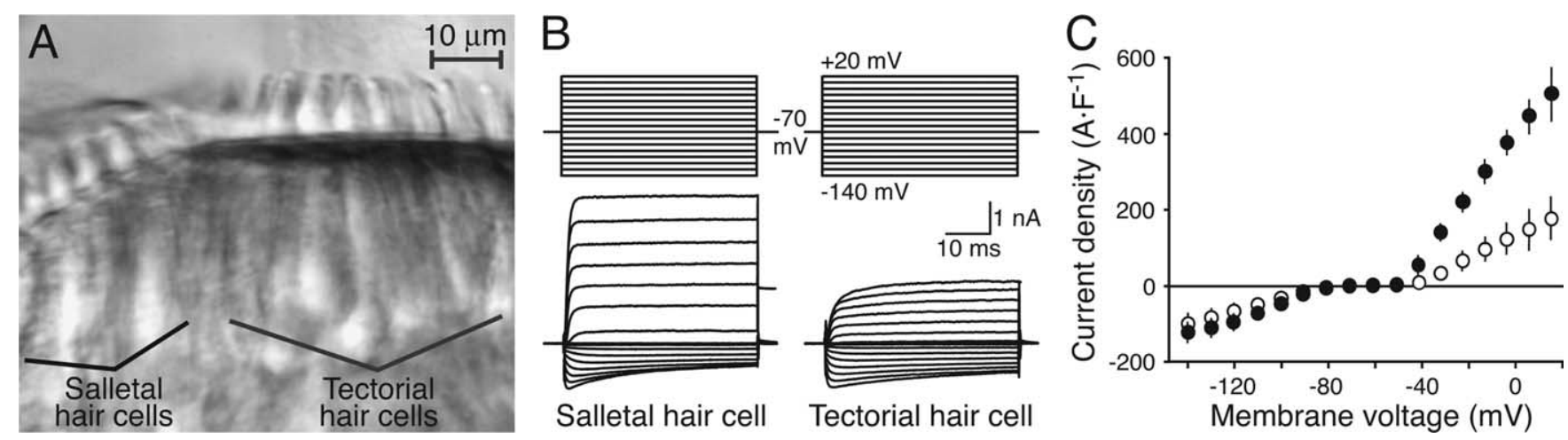

Figure 2. Electrophysiological recordings from hair cells. $A$, A differential interference contrast micrograph depicts a slice from the high-frequency region of the gecko's basilar papilla. Salletal hair cells and tectorial hair cells display cylindrical profiles. The hair bundles are attached to the cognate tectorial structures. $\boldsymbol{B}$, Total ionic currents were evoked in hair cells of the two types by voltage pulses from a holding potential of $-70 \mathrm{mV}$ to values from -140 to $+20 \mathrm{mV}$ in $10 \mathrm{mV}$ steps. C, The steady-state voltage- current relationships for the two populations of hair cells show rectification in both the depolarizing and the hyperpolarizing direction.

A

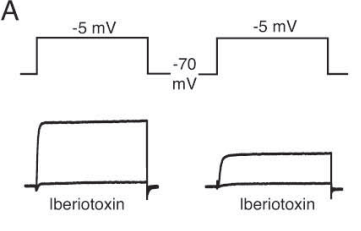

Salletal hair cell Tectorial hair cell $\prod_{20 \mathrm{~ms}} \mathrm{nA}$

D
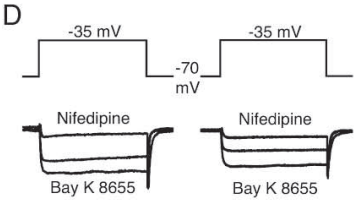

Salletal hair cell Tectorial hair cell

$$
\prod_{20 \mathrm{~ms}}^{200 \mathrm{pA}}
$$

B

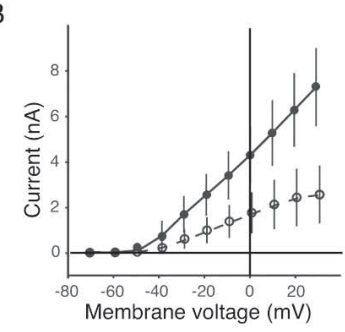

E

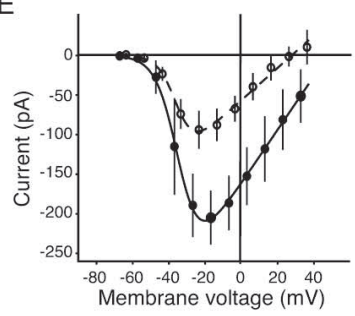

C

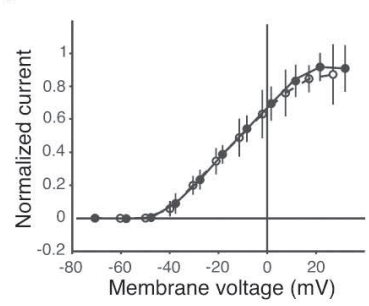

F

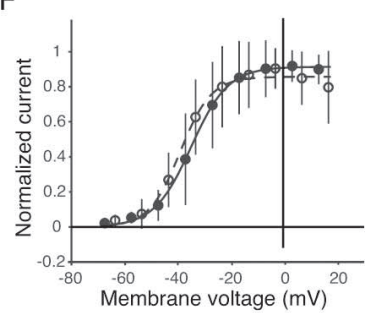

Figure 3. Characterization of $\mathrm{K}^{+}$and $\mathrm{Ca}^{2+}$ currents. $A$, Depolarizations to $-5 \mathrm{mV}$ from a holding potential of $-70 \mathrm{mV}$ revealed an outward current that was blocked by external application of $100 \mathrm{~nm}$ iberiotoxin. $\boldsymbol{B}$, Steady-state voltage-current relationships show greater outward current for salletal hair cells $(\bullet)$ than for tectorial ones $(O)$. C, The normalized voltagecurrent relationships for salletal and tectorial hair cells demonstrate same voltage dependences. $\boldsymbol{D}$, In the presence of $20 \mathrm{~mm}$ TEA, voltage pulses to $-35 \mathrm{mV}$ evoked a noninactivating inward current that was enhanced by the L-type $\mathrm{Ca}^{2+}$-channel agonist Bay $\mathrm{K} 8644$ at a concentration of $5 \mu \mathrm{m}$ and partially blocked by the antagonist nifedipine at a concentration of $50 \mu \mathrm{m}$. $E$, Steady-state voltage- current relationships were fit with Equation 2 (salletal hair cells: $V_{1 / 2}=-34 \mathrm{mV}, E_{\mathrm{rev}}=48 \mathrm{mV}, k=6 \mathrm{mV}$; tectorial hair

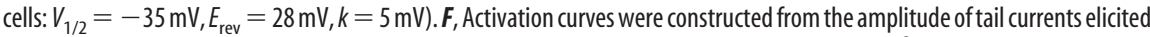
during hyperpolarization to $-70 \mathrm{mV}$ after depolarizing pulses to the indicated potentials. The $\mathrm{Ca}^{2+}$ channels in salletal and tectorial hair cells activate at potentials positive to $-50 \mathrm{mV}$ and exhibit identical activation curves. The activation curves were fit with Equation 1 (salletal hair cells: $V_{1 / 2}=-35 \mathrm{mV}, k=6 \mathrm{mV}$; tectorial hair cells: $V_{1 / 2}=-39 \mathrm{mV}, k=5 \mathrm{mV}$ ).

hair cells would be expected to display characteristic frequencies of $4-5 \mathrm{kHz}$ (Manley et al., 1999).

Salletal hair cells had higher membrane capacitances (10.8 \pm $1.5 \mathrm{pF} ; n=53)$ than tectorial hair cells $(8.3 \pm 1.3 \mathrm{pF} ; n=46 ; p<$ 0.001 , Student's $U$ test). Although the capacitances of both cell types showed relatively stable values, those of salletal hair cells increased slightly during prolonged recordings, perhaps as a result of $\mathrm{Ca}^{2+}$-triggered exocytosis. Salletal hair cells had resting potentials averaging $-66 \pm 14 \mathrm{mV}(n=53$; range, -42 to -90 $\mathrm{mV}$ ); tectorial hair cells displayed a mean resting potential of $-68 \pm 12 \mathrm{mV}(n=46$; range, -45 to $-85 \mathrm{mV})$. Both cell types responded to the injection of depolarizing current with damped voltage oscillations at frequencies far below their expected natural frequencies. This observation suggests that the high- frequency tuning in these cells is not achieved through electrical resonance of their membranes. For both cell types, the steady-state voltage-current relationships displayed strong nonlinearities indicative of voltage-activated conductances (Fig. $2 B, C)$.

Depolarizing steps revealed a pharmacologically distinct outward current that activated at approximately $-40 \mathrm{mV}$ and peaked at $+20 \mathrm{mV}$ (Fig. $3 A-C$ ). The time constant of activation ranged from $2.5 \mathrm{~ms}$ at $-40 \mathrm{mV}$ to $1 \mathrm{~ms}$ at $0 \mathrm{mV}$. Salletal hair cells displayed currents about three times as large as those of tectorial hair cells (Fig. $3 B)$. The peak current density measured at $+20 \mathrm{mV}$ was $610 \pm 130 \mathrm{~A} \cdot \mathrm{F}^{-1}$ in salletal hair cells $(n=16)$ compared with $270 \pm$ $140 \mathrm{~A} \cdot \mathrm{F}^{-1}$ in tectorial hair cells $(n=17)$, a significant difference $(p<0.001$, Student's $t$ test). Normalized voltage-current relationships for the two populations of hair cells (Fig. 3B) demonstrated that the currents differ in amplitude but not in voltage sensitivity (Fig. 3C).

In all 33 tested hair cells of both types, $20 \mathrm{~mm}$ tetraethylammonium (TEA) eliminated $>95 \%$ of the outward current at 10 $\mathrm{mV}$ (data not shown). Iberiotoxin, a selective blocker of large-conductance (BK), $\mathrm{Ca}^{2+}$-activated $\mathrm{K}^{+}$channels, reduced the outward current by an average of $83 \%$ in seven experiments (Fig. $3 A$ ). The remaining outward current was eliminated by the subsequent application of TEA. Thus, the difference in the total outward currents of salletal and tectorial hair cells stems chiefly from differences in the expression of BK channels.

When outward currents were blocked, depolarizing steps revealed an inward $\mathrm{Ca}^{2+}$ current (Fig. 3D). This current showed almost no inactivation during a $50 \mathrm{~ms}$ depolarization and was blocked by nifedipine, characteristics of the L-type $\mathrm{Ca}^{2+}$ current commonly encountered in hair cells (Lewis and Hudspeth, 1983; Hudspeth and Lewis, 1988; Zidanic and Fuchs, 1995). Consistent with this assignment, the L-type channel agonist Bay K 8644 increased the steady-state current and prolonged the tail current (Fig. 3D). 
The steady-state voltage-current relationships displayed the inward inflection characteristic of $\mathrm{Ca}^{2+}$ currents (Fig. $3 E$ ). The inward current peaked at a potential of $-20 \pm 3 \mathrm{mV}$ in salletal hair cells and of $-22 \pm 4 \mathrm{mV}$ in tectorial hair cells. Fitting the steady-state relationships with Equation 2 indicated that the voltage dependence of $\mathrm{Ca}^{2+}$ channels did not differ significantly between hair cells of the two types. The currents reversed at different potentials in the two types of hair cells, however, indicating differential contamination by outward currents through $\mathrm{K}^{+}$ channels. Boltzmann fits of the activation curves constructed from tail currents showed similar voltage dependences in the two populations (Fig. $3 F$ ). The activation time constant of the current ranged from 0.5 to $0.9 \mathrm{~ms}$ at $-25 \mathrm{mV}$. Although cells of the two types exhibited similar $\mathrm{Ca}^{2+}$ currents, the current amplitudes differed: the peak amplitude averaged $-204 \pm 24 \mathrm{pA}$ in salletal hair cells and $-94 \pm 23 \mathrm{pA}$ in tectorial hair cells. Moreover, when these current amplitudes were normalized by the cellular capacitances, salletal hair cells displayed greater current densities $\left(21.7 \pm 2.7 \mathrm{~A} \cdot \mathrm{F}^{-1} ; n=25\right)$ than tectorial ones $(12.2 \pm 3.4$ $\mathrm{A} \cdot \mathrm{F}^{-1} ; n=27 ; p<0.001$, Student's $t$ test).

These results indicate that the hair cells covered by distinct tectorial structures differ electrophysiologically as well. Like mammalian inner hair cells and archosaurian tall hair cells, salletal hair cells display larger macroscopic $\mathrm{Ca}^{2+}$ and $\mathrm{Ca}^{2+}$ sensitive $\mathrm{K}^{+}$conductances than do the corresponding hair cells of the other type.

\section{Innervation pattern of the gecko's hair cells}

Because hair cells of the two classes in mammals and archosaurs are distinguished by their innervation patterns, we next investigated the innervation of the tokay gecko's basilar papilla. After labeling auditory nerve fibers with an antibody against neurofilament-associated protein 200, which is expressed in both afferent and efferent fibers (Hafidi et al., 1990), we used laserscanning confocal microscopy to reconstruct the peripheral trajectories of the axons innervating the hair cells in five cochleas. Because there is no efferent innervation in the high-frequency region of lizard basilar papillas (Manley, 1990), the auditory nerve fibers in this region represent only afferent terminals, the distal axonal segments connecting hair cells to eighth-nerve neurons.

In the low-frequency region, we found that nerve terminals entering the epithelium projected to both the neural and the abneural edges of the basilar papilla (Fig. $4 \mathrm{~B}, \mathrm{C}$ ); this observation accords with previous studies (Miller and Beck, 1988). In contrast, afferent terminals of the high-frequency region innervated exclusively the abneural side, the domain of the salletal hair cells (Fig. $4 B, D$ ). This distinctive pattern of innervation in the highfrequency region of the basilar papilla was confirmed by labeling auditory fibers with the lipophilic tracer DiI: labeled nerve fibers extended their projections to only the salletal hair cells (data not shown).

To better visualize the innervation of hair cells, we cut cross sections at different locations along the tonotopic axis of three basilar papillas, immunolabeled auditory-nerve fibers with an antibody against a neurofilament protein, and marked hair and supporting cells with a nonspecific antiserum. In the lowfrequency third of each papilla, the region covered by a tectorial mesh, all the hair cells received innervation (Fig. 4E). Throughout the high-frequency two-thirds, however, labeled axons entered the epithelium and projected exclusively to salletal hair cells (Fig. $4 F$ ). The tectorial hair cells were rarely, if ever, contacted by auditory nerve fibers. These results demonstrate that the pattern
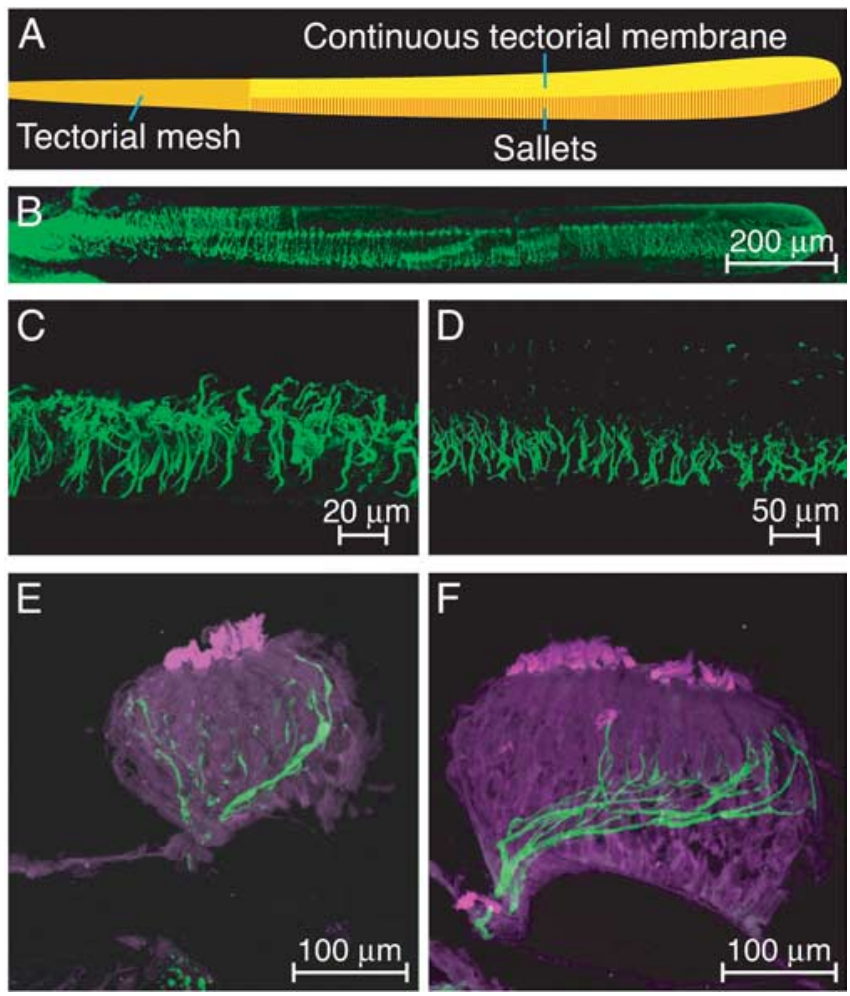

Figure 4. Innervation pattern of the basilar papilla. $A$, A schematic representation shows the regions covered by different tectorial structures. $\boldsymbol{B}$, A stack of confocal images of an intact basilar papilla depicts the auditory nerve fibers labeled for neurofilament-associated proteins with the NF200 antiserum (green). Incoming nerve fibers in the low-frequency region project to both the neural and abneural sides. In the high-frequency region, however, neurites terminate exclusively on the abneural edge, where the sallets are located. C, A higher-magnification micrograph shows that the innervation in the low-frequency region extends the entire width of the basilar papilla. $\boldsymbol{D}$, In the high-frequency region, in contrast, afferent terminals are confined to the abneural, salletal edge. $\boldsymbol{E}$, A cross section of the basal, low-frequency region of the basilar papilla shows that innervation (green) reaches hair cells located on both the neural and the abneural edges. All cells are labeled with a nonspecific antiserum (purple). $\boldsymbol{F}$, In the highfrequency portion of the basilar papilla, only salletal hair cells receive innervation.

of innervation in the gecko's basilar papilla varies systematically in conjunction with the arrangement of tectorial structures along the sensory epithelium.

\section{Electron-microscopic analysis of cochlear synapses}

Electron micrographs of the high-frequency region of the basilar papilla showed that salletal hair cells were narrow and cylindrical, with a prominent nucleus located toward the basal end of each cell and mitochondria clustered at both the apical and basal poles (Fig. 5A). The apical aspect of a cell revealed the prominent cuticular plate from which the beveled, mechanoreceptive hair bundle protruded.

On the abneural side of the apical portion of the basilar papilla, electron microscopy revealed an abundance of nerve fibers in intimate contact with the salletal hair cells. Individual axonal terminals received afferent synapses from one or more hair cells (Fig. 5B). These contacts displayed the morphological specializations characteristic of hair-cell synapses, including synaptic ribbons with associated vesicles, postsynaptic densities, and coated vesicles indicative of vigorous endocytotic activity adjacent to the active zone.

Although electron microscopy disclosed that tectorial hair cells were of similar structure (Fig. 5C), it confirmed that the neural side of the basilar papilla was devoid of innervation. Tec- 

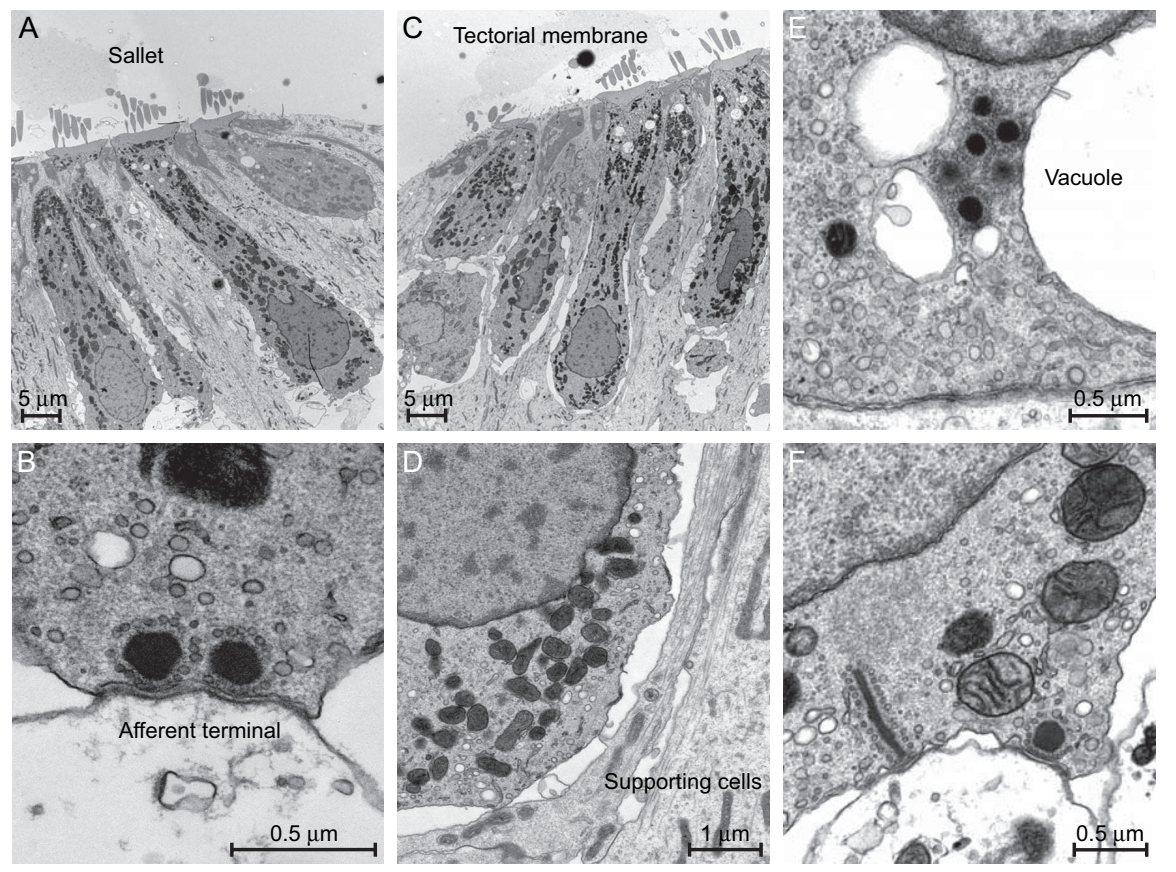

Figure 5. Electron-microscopic analysis of the innervation pattern. $A$, A low-magnification view shows four salletal hair cells with hair bundles protruding from their cuticular plates. $\boldsymbol{B}$, A higher-magnification micrograph depicts a classical ribbon synapse with two adjacent active zones marked by presynaptic ribbons and postsynaptic densities. C, Parts of six tectorial hair cells appear in a low-magnification view of the basilar papilla. $D$, A higher-magnification image of the boundary of one tectorial hair cell shows evidence neither of synapses nor of nerve fibers running between the hair cells. $\boldsymbol{E}$, The basolateral cytoplasm of a tectorial hair cell contains a cluster of at least six heterotypic synaptic bodies adjacent to the lower pole of the nucleus and well away from the membrane surface. $\boldsymbol{F}$, An individual salletal hair cell is able to form ribbons of two types. The spherical structure on the right, often called a presynaptic dense body, is typical of hair cells. The structure on the left is instead a classical synaptic ribbon of the type first described in retinal photoreceptors.

torial hair cells lay in close contact with supporting cells, and neither neurites nor terminals were apparent. Closer inspection of the basolateral aspect of the cells disclosed no features of functional synapses (Fig. 5D). However, some tectorial hair cells retained structures that have been termed heterotypic synaptic bodies (Miller and Beck, 1987). Consisting of clustered synaptic ribbons with associated vesicles, these organelles generally occurred adjacent to cytoplasmic vacuoles but distant from the cellular surface (Fig. 5E).

We analyzed the distribution of synaptic ribbons along the basilar papilla by using a total of 326 sections, grouped in series of 22-38 consecutive sections from each of seven cochleas, to reconstruct the synaptic structures in parts of 32 hair cells. Synaptic ribbons were encountered along the entirety of the basilar papilla. In the low-frequency portion of the papilla covered by a continuous tectorial membrane, hair cells in the neural and abneural halves showed equivalent numbers of ribbons. In the highfrequency region, synaptic ribbons were found exclusively in salletal hair cells, where their density per unit of somatic volume averaged $0.063 \pm 0.016 \mu \mathrm{m}^{-3}(n=7$ cochleas $)$. Although most of these ribbons adopted the spherical configuration characteristic of hair cells, a few manifested the flattened form typical of retinal photoreceptors and bipolar cells (Fig. $5 F$ ). In no instance did we observe a synaptic ribbon in a tectorial hair cell. Heterotypic synaptic bodies were rarer than synaptic ribbons: only five tectorial hair cells displayed these structures, which occurred in clusters with a density of $0.009 \pm 0.011 \mu \mathrm{m}^{-3}(n=7)$. Salletal hair cells lacked heterotypic synaptic bodies.

\section{Discussion}

The four orders of contemporary amniotes, chelonians (turtles), mammals, archosaurs (crocodilians and birds), and lepidosaurs (lizards and snakes), diverged before the appearance of modern features of the inner ear (Clack, 1997, 2002; Manley, 2000). Mammals and archosaurs subsequently evolved two classes of hair cells distinguished in each instance by their structure, innervation, and presumed function. Our data suggest that a similar specialization occurred independently in the high-frequency cochlear region of certain lepidosaurs.

\section{Two classes of hair cells}

Mammalian inner hair cells and archosaurian tall hair cells are characterized by relatively large ionic currents and copious afferent innervation. Because these hair cells constitute the dominant input to the afferent fibers of the eighth cranial nerve, the only conduit through which auditory information reaches the CNS, there is no doubt that their principal function lies in mechanoelectrical transduction and synaptic transmission. We found that the salletal hair cells in the high-frequency region of the gecko's cochlea resemble these signaling cells. Consistent with their role in transduction and transmission, salletal hair cells have provided the only identified inputs to high-frequency nerve fibers from which auditory responses have been recorded in the tokay gecko (Manley et al., 1999).

The outer hair cells of mammals and the short hair cells of archosaurs constitute a second class of receptors defined by sparse or absent afferent innervation and small ionic currents associated with neurotransmitter release. Cells of this type are thought to mediate the cochlear active process, the cardinal manifestations of which are amplification, frequency tuning, compressive nonlinearity, and spontaneous otoacoustic emission (Manley and Köppl, 1998; Manley, 2000, 2001). Although all four of these characteristics can be explained in anurans by active hair-bundle motility (Martin and Hudspeth, 1999, 2001; Martin et al., 2003), only circumstantial evidence links them to particular hair cells in amniotes. In mammals, chemical extirpation of outer hair cells compromises auditory sensitivity (Dallos and Harris, 1978). Eliminating the expression of prestin, the putative motor protein of outer hair cells, also results in diminished auditory responsiveness (Liberman et al., 2002; Cheatham et al., 2004). However, the extensive death of both inner and outer hair cells associated with the molecular lesion clouds the interpretation of this result. There is no direct evidence for a contribution to the active process by archosaurian short hair cells, but their hair bundles are capable of active motility (Hudspeth et al., 2000), and their structure and innervation accord with such a role (Fettiplace and Fuchs, 1999).

Although the point remains to be proved, the tectorial hair cells of the gecko's basilar papilla, which display relatively small ionic currents and completely lack afferent innervation, appar- 
ently fall into the class of receptors associated with the active process. Because the specialization of the protein prestin for electromotility is thought to be unique to mammals (Franchini and Elgoyhen, 2006) and has been shown not to occur in at least some reptiles (He et al., 2003), tectorial hair cells probably contribute to the active process through active hair-bundle motility. In the lepidosaurian cochlea, acoustic stimuli produce a pressure difference across the basilar membrane that rocks the basilar papilla back and forth about a hinge along the neural edge of the structure (Frishkopf and DeRosier, 1983; Holton and Hudspeth, 1983; Aranyosi and Freeman, 2005). In the gecko's cochlea, such a motion would be expected to deflect the hair bundles of tectorial hair cells and thus to excite them. The hair bundles might then produce a feedback force that accentuates the rocking motion of the papilla, perhaps through their mechanical coupling with the tectorial membrane and spindle body. The salletal hair cells would, meanwhile, sense the enhanced movements of the papilla, transduce them into receptor potentials, and transmit the information across afferent synapses to eighth-nerve fibers.

\section{Functional significance of dichotomous hair cells}

What selective advantage has led in three separate evolutionary events to a distinction between the two classes of hair cells? It seems probable that this advantage is associated with highfrequency hearing, because the separation occurs in mammals, which include the vertebrates with the highest frequency responsiveness; in archosaurs, whose hearing extends to frequencies exceeding $10 \mathrm{kHz}$; and in geckos, whose ears are tuned to the highest frequencies among lepidosaurs (Wever et al., 1963; Manley and Köppl, 1998; Manley, 2000). One cause that may have impelled the two classes of hair cells to their separation is an irreconcilable conflict between the requirements for efficient mechanoelectrical transduction and for effective mechanical amplification of highfrequency sounds.

Like other cellular membranes, the plasmalemma of the hair cell acts as an electrical integrator, the time constant of which equals the product of its capacitance and resistance. For highfrequency stimulation, the period of a stimulus is smaller than this time constant, so voltage response of a hair cell is proportional to the temporal integral of the transduction current. The steepest part of the relationship between hair-bundle displacement and channel open probability occurs at an open probability of 0.5 . Because the relationship is symmetrical about that point, however, the transduction current for a hair bundle poised there would integrate to zero: the voltage response would vanish. For channels governed by a two-state Boltzmann distribution, the greatest voltage response would instead occur for open probabilities of $1 / 2 \pm \sqrt{ } 3 / 6$, or $\sim 0.79$ and 0.21 . The latter value would be preferable because it would lower the metabolic cost associated with removing the cations that enter through transduction channels at rest. When studied in the fluid environment of the intact cochlea, mammalian inner hair cells sensitive to high frequencies in fact display resting open probabilities of 0.1-0.2 (Russell and Sellick, 1983; Russell and Kössl, 1991).

Two mechanisms have been advanced as candidates to mediate the active process of the inner ear. The first, membrane-based electromotility, is powered by changes in membrane potential. For stimulation at relatively low frequencies, this process should be most effective when channel gating is most sensitive, specifically when the resting open probability of transduction channels lies near 0.5. It remains unclear how electromotility can operate during high-frequency stimulation, when the time constant of the membrane restricts changes in the membrane potential
(Santos-Sacchi, 1992; Gale and Ashmore, 1997; Ospeck et al., 2003). The second possible active process, active hair-bundle motility, depends on mechanical events during the gating of transduction channels (Hudspeth et al., 2000). This process is most effective when the most transduction channels are changing back and forth between their closed and open states, again at a resting open probability near 0.5 (Hudspeth et al., 2000). No information is available from archosaurs and lepidosaurs on the resting open probability of transduction channels in the putatively amplifying receptors, respectively, short hair cells and tectorial hair cells. Outer hair cells, the receptors likely to mediate the active process in mammals, are thought to use electromotility (Dallos, 1992; Nobili et al., 1998; Dallos et al., 2006) but depend, at least in part, on active hair-bundle motility (Chan and Hudspeth, 2005a,b; Kennedy et al., 2005, 2006). In keeping with the arguments above, outer hair cells responsive to high frequencies and studied in situ display a resting open probability of $\sim 0.5$ (Russell and Kössl, 1991; Cody and Russell, 1995; Kirk et al., 1997).

For hair cells responsive to relatively low frequencies, the most sensitive point on the displacement-response relationship lies in the region of its greatest slope, near its center. The resting open probability in such cells, which is determined in part by the ambient $\mathrm{Ca}^{2+}$ concentration, is $\sim 0.3$ in both the bullfrog's sacculus and the turtle's cochlea (Corey and Hudspeth, 1983; Farris et al., 2006). Because this open probability suffices for mechanical amplification by active hair-bundle motility as well, one type of hair cell can simultaneously optimize both aspects of its responsiveness. To respond efficiently at high frequencies, however, an individual hair cell must favor either mechanical or electrical aspects of sound transduction. Evolution has thrice overcome this restriction by assigning the two aspects of peripheral auditory signaling, synaptic signaling and mechanical amplification, to discrete classes of hair cells.

\section{References}

Aranyosi AJ, Freeman DM (2005) Two modes of motion of the alligator lizard cochlea: measurements and model predictions. J Acoust Soc Am 118:1585-1592.

Authier S, Manley GA (1995) A model of frequency tuning in the basilar papilla of the Tokay gecko, Gekko gecko. Hear Res 82:1-13.

Chan DK, Hudspeth AJ (2005a) $\mathrm{Ca}^{2+}$ current-driven nonlinear amplification by the mammalian cochlea in vitro. Nat Neurosci 8:149-155.

Chan DK, Hudspeth AJ (2005b) Mechanical response of the organ of Corti to acoustic and electrical stimulation in vitro. Biophys J 89:4382-4395.

Cheatham MA, Huynh KH, Gao J, Zuo J, Dallos P (2004) Cochlear function in Prestin knockout mice. J Physiol (Lond) 560:821-830.

Clack JA (1997) The evolution of tetrapod ears and the fossil record. Brain Behav Evol 50:198-212.

ClackJA (2002) Patterns and processes in the early evolution of the tetrapod ear. J Neurobiol 53:251-264.

Cody AR, Russell IJ (1995) Time-varying voltage responses of mammalian hair cells to isoamplitude acoustic stimulation. Aud Neurosci 1:351-361.

Corey DP, Hudspeth AJ (1983) Kinetics of the receptor current in bullfrog saccular hair cells. J Neurosci 3:962-976.

Dallos P (1992) The active cochlea. J Neurosci 12:4575-4585.

Dallos P, Harris D (1978) Properties of auditory nerve responses in absence of outer hair cells. J Neurophysiol 41:365-383.

Dallos P, Zheng J, Cheatham MA (2006) Prestin and the cochlear amplifier. J Physiol (Lond) 576:37-42.

Farris HE, Wells GB, Ricci AJ (2006) Steady-state adaptation of mechanotransduction modulates the resting potential of auditory hair cells, providing an assay for endolymph $\left[\mathrm{Ca}^{2+}\right]$. J Neurosci 26:12526-12536.

Fettiplace R, Fuchs PA (1999) Mechanisms of hair cell tuning. Annu Rev Physiol 61:809-834.

Fettiplace R, Hackney CM (2006) The sensory and motor roles of auditory hair cells. Nat Rev Neurosci 7:19-29.

Franchini LA, Elgoyhen AB (2006) Adaptive evolution in mammalian pro- 
teins involved in cochlear outer hair cell electromotility. Mol Phylogen Evol 41:622-635.

Frishkopf LS, DeRosier DJ (1983) Mechanical tuning of free-standing stereociliary bundles and frequency analysis in the alligator lizard cochlea. Hear Res 12:393-404.

Gale JE, Ashmore JF (1997) An intrinsic frequency limit to the cochlear amplifier. Nature 389:63-66.

Hafidi A, Despres G, Romand R (1990) Cochlear innervation in the developing rat: an immunocytochemical study of neurofilament and spectrin proteins. J Comp Neurol 300:153-161.

He DZZ, Beisel KW, Chen L, Ding D-L, Jia S, Fritzsch B, Salvi R (2003) Chick hair cells do not exhibit voltage-dependent somatic motility. J Physiol (Lond) 546:511-520.

Holton T, Hudspeth AJ (1983) A micromechanical contribution to cochlear tuning and tonotopic organization. Science 222:508-510.

Hudspeth AJ, Lewis RS (1988) Kinetic analysis of voltage- and iondependent conductances in saccular hair cells of the bull-frog Rana catesbeiana. J Physiol (Lond) 400:237-274.

Hudspeth AJ, Choe Y, Mehta AD, Martin P (2000) Putting ion channels to work: mechanoelectrical transduction, adaptation, and amplification by hair cells. Proc Natl Acad Sci USA 97:11765-11772.

Kennedy HJ, Crawford AC, Fettiplace R (2005) Force generation by mammalian hair bundles supports a role in cochlear amplification. Nature 433:880-883.

Kennedy HJ, Evans MG, Crawford AC, Fettiplace R (2006) Depolarization of cochlear outer hair cells evokes active hair bundle motion by two mechanisms. J Neurosci 26:2757-2766.

Kirk DL, Moleirinho A, Patuzzi RB (1997) Microphonic and DPOAE measurements suggest a micromechanical mechanism for the "bounce" phenomenon following low-frequency tones. Hear Res 112:69-86.

Knirsch M, Brandt N, Braig C, Kuhn S, Hirt B, Munkner S, Knipper M, Engel J (2007) Persistence of $\mathrm{Ca}_{\mathrm{v}} 1.3 \mathrm{Ca}^{2+}$ channels in mature outer hair cells supports outer hair cell afferent signaling. J Neurosci 27:6442-6451.

Kros CJ, Crawford AC (1990) Potassium currents in inner hair cells isolated from the guinea-pig cochlea. J Physiol (Lond) 421:263-291.

Kros CJ, Ruppersberg JP, Rüsch A (1998) Expression of a potassium current in inner hair cells during development of hearing in mice. Nature 394:281-284.

Lewis RS, Hudspeth AJ (1983) Voltage- and ion-dependent conductances in solitary vertebrate hair cells. Nature 304:538-541.

Liberman MC, Gao J, He DZZ, Wu X, Jia S, Zuo J (2002) Prestin is required for electromotility of the outer hair cell and for the cochlear amplifier. Nature 419:300-304.

Manley GA (1990) Peripheral hearing mechanisms in reptiles and birds. Berlin: Springer.

Manley GA (2000) Cochlear mechanisms from a phylogenetic viewpoint. Proc Natl Acad Sci USA 97:11736-11743.

Manley GA (2001) Evidence for an active process and a cochlear amplifier in nonmammals. J Neurophysiol 86:541-549.

Manley GA, Köppl C (1998) Phylogenetic development of the cochlea and its innervation. Curr Opin Neurobiol 8:468-474.
Manley GA, Köppl C, Sneary M (1999) Reversed tonotopic map of the basilar papilla in Gekko gecko. Hear Res 131:107-116.

Manley GA, Kirk DL, Köppl C, Yates GK (2001) In vivo evidence for a cochlear amplifier in the hair-cell bundle of lizards. Proc Natl Acad Sci USA 98:2826-2831.

Martin P, Hudspeth AJ (1999) Active hair-bundle movements can amplify a hair cell's response to oscillatory mechanical stimuli. Proc Natl Acad Sci USA 96:14306-14311.

Martin P, Hudspeth AJ (2001) Compressive nonlinearity in the hair bundle's active response to mechanical stimulation. Proc Natl Acad Sci USA 98:14386-14391.

Martin P, Mehta AD, Hudspeth AJ (2000) Negative hair-bundle stiffness betrays a mechanism for mechanical amplification by the hair cell. Proc Natl Acad Sci USA 97:12026-12031.

Martin P, Bozovic D, Choe Y, Hudspeth AJ (2003) Spontaneous oscillation by hair bundles of the bullfrog's sacculus. J Neurosci 23:4533-4548.

Martinez-Dunst C, Michaels RL, Fuchs PA (1997) Release sites and calcium channels in hair cells of the chick's cochlea. J Neurosci 17:9133-9144.

Miller MR (1973) A scanning electron microscope study of the papilla basilaris of Gekko gecko. Z Zellforsch Mikrosk Anat 136:307-328.

Miller MR, Beck J (1987) Heterotopic synaptic bodies in the auditory hair cells of adult lizards. Anat Rec 218:338-344.

Miller MR, Beck J (1988) Auditory hair cell innervational patterns in lizards. J Comp Neurol 271:604-628.

Nobili R, Mammano F, Ashmore J (1998) How well do we understand the cochlea? Trends Neurosci 21:159-167.

Ospeck M, Dong X, Iwasa KH (2003) Limiting frequency of the cochlear amplifier based on electromotility of outer hair cells. Biophys J 84:739-749.

Pyott SJ, Glowatzki E, Trimmer JS, Aldrich RW (2004) Extrasynaptic localization of inactivating calcium-activated potassium channels in mouse inner hair cells. J Neurosci 24:9469-9474.

Ricci AJ, Crawford AC, Fettiplace R (2002) Mechanisms of active hair bundle motion in auditory hair cells. J Neurosci 22:44-52.

Russell IJ, Kössl M (1991) The voltage responses of hair cells in the basal turn of the guinea-pig cochlea. J Physiol (Lond) 435:493-511.

Russell IJ, Sellick PM (1983) Low-frequency characteristics of intracellularly recorded receptor potentials in guinea-pig cochlear hair cells. J Physiol (Lond) 338:179-206.

Santos-Sacchi J (1992) On the frequency limit and phase of outer hair cell motility: effects of the membrane filter. J Neurosci 12:1906-1916.

Skinner LJ, Enee V, Beurg M, Jung HH, Ryan AF, Hafidi A, Aran JM, Dulon D (2003) Contribution of $\mathrm{BK} \mathrm{Ca}^{2+}$-activated $\mathrm{K}^{+}$channels to auditory neurotransmission in the guinea pig cochlea. J Neurophysiol 90:320-332.

Smotherman MS, Narins PM (1999) The electrical properties of auditory hair cells in the frog amphibian papilla. J Neurosci 19:5275-5292.

Wever EG, Vernon JA, Peterson EA, Crowley DE (1963) Auditory responses in the Tokay Gecko. Proc Natl Acad Sci USA 50:806-811.

Zidanic M, Fuchs PA (1995) Kinetic analysis of barium currents in chick cochlear hair cells. Biophys J 68:1323-1336. 